\title{
Continuous Saccharification of Laminarin by Immobilized Laminarinase ULam111 Followed by Ethanol Fermentation with a Marine-Derived Yeast
}

\author{
Daisuke Mitsuya ${ }^{1}$, Masashi Yamamoto ${ }^{1}$, Masahiko Okai' ${ }^{1}$, Akira Inoue ${ }^{2}$, Tomohiro Suzuki², \\ Takao Ojima ${ }^{2}$, Naoto Urano ${ }^{{ }^{*}}$
}

${ }^{1}$ Laboratory of Marine Biochemistry, Department of Ocean Sciences, Tokyo University of Marine Science and Technology, Tokyo, Japan

${ }^{2}$ Laboratory of Marine Biotechnology and Microbiology, Graduate School of Fisheries Sciences, Hokkaido University, Hakodate, Japan

Email: *urano@kaiyodai.ac.jp

How to cite this paper: Mitsuya, D., Yamamoto, M., Okai, M., Inoue, A., Suzuki, T., Ojima, T. and Urano, N. (2017) Continuous Saccharification of Laminarin by Immobilized Laminarinase ULam111 Followed by Ethanol Fermentation with a Marine-Derived Yeast. Advances in Microbiology, 7, 387-403.

https://doi.org/10.4236/aim.2017.75032

Received: March 30, 2017

Accepted: May 23, 2017

Published: May 27, 2017

Copyright $\odot 2017$ by authors and Scientific Research Publishing Inc. This work is licensed under the Creative Commons Attribution International License (CC BY 4.0).

http://creativecommons.org/licenses/by/4.0/

(c) (i) Open Access

\begin{abstract}
We isolated a novel laminarinase ULam111 from Flavobacterium sp. strain UMI-01. Purified ULam111 showed degradation activity against laminarin with the specific activity of $224 \pm 18 \mathrm{U} / \mathrm{mg}$ at $30^{\circ} \mathrm{C}$ and $\mathrm{pH}$ 6.0. Its optimum temperature was $50^{\circ} \mathrm{C}$, and degradation activities against laminarin were observed at $4^{\circ} \mathrm{C}-80^{\circ} \mathrm{C}$. With a laminarin degradation system, we investigated the preparation and properties of immobilized ULam111 with the use of the 11 types of carriers. The high activity recoveries of immobilized ULam111 were as follows: $19.4 \%$ for IB-S60P carrier beads (the non-ionic type), $15.6 \%$ for IB-S60S carrier beads (the non-ionic type), $11.9 \%$ for IB-150P carrier beads (the covalent type), and $7.1 \%$ for IB-C435 carrier beads (the cationic type). With the repeated use of immobilized ULam111, the enzyme activities immobilized on IB-S60S and those on IB-S60P remained at $40 \%$ and $30 \%$ respectively after the sixth trial. We selected IB-S60S as suitable beads for enzyme immobilization, and we attempted to construct a reactor system with ULam111 immobilized on IB-S60S beads. In this system, $1.2-1.9 \mathrm{~g} / \mathrm{L}$ glucose was repeatedly produced from $30 \mathrm{mg} / \mathrm{mL}$ laminarin solutions after $20 \mathrm{hr}$ when the reactor operation was repeated 10 times. We examined ethanol fermentation from the saccharified solutions with a marine-derived yeast (Saccharomyces cerevisiae C-19), and $0.51-0.58 \mathrm{~g} / \mathrm{L}$ bioethanol was produced from the saccharified solution that contained $1.71-1.86 \mathrm{~g} / \mathrm{L}$ of glucose.
\end{abstract}

\section{Keywords}

Laminarin, Laminarinase, $\beta$-1,3-Glucanase, Immobilization, Ethanol Fermentation 


\section{Introduction}

Seaweeds account for the majority of the worldwide mass of marine organisms. Of these, brown algae produce unique and edible polysaccharides such as laminarin, alginate, and fucoidan. Laminarin is a storage polysaccharide that belongs to the family of $\beta$-glucans, and its main chain consists of glucose through $\beta-1,3$ glycosidic bonds. In addition, chains via $\beta-1,6$ glycosidic bonds partially branch [1] [2]. Laminarin is classified into two types based on their terminal structures. Accordingly, the M-chain and the G-chain have D-mannitol and glucose at reducing end, respectively [3]. The content of laminarin in brown algae is up to $32 \%-35 \%$ of dry weight in Laminaria digitata, Laminaria hyperborea, and Saccharina latissima and these values change seasonally [4]. To date, laminarinases are found in some species of bacteria, fungi, yeasts, and marine invertebrates [5]. The ratio between the $\beta-1,3$ and $\beta-1,6$ bonds in laminarin was 7:1 in L. digitata [5] and 3:2 in Eisenia bicyclis [6], and $\beta$-1,3-glucanase have a primary role in the effective degradation of laminarin. According to the CAZy database [7], $\beta-1,3-$ glucanases are classified into glycosidehydrolase families (GH) $16,17,55,64,81$, and 128. Of these, $\beta$-1,3-glucanases belonging to the GH16 family are abundant and well characterized. Labourel et al. [8] reported the characterization of GH16 laminarinase from Zobellia galactanivorans and solved its structure, suggesting that a bacterium associated with brown algae in nature uses glucose derived from brown algal laminarin.

Seaweeds are thought to be promising biomass feedstock for bioethanol production because they contain no lignin; thus, a simple biorefinery process can be used to produce sugars from seaweed. For example, polysaccharides can be easily decomposed from the seaweed to sugars with enzymatic treatment [9] [10]. As high ethanol-fermenting yeasts (e.g., Saccharomyces cerevisiae) cannot degrade polysaccharides, it is important to degrade the polysaccharides to mono- or oligo-saccharides. Thus, for the utilization of the wastes of processed brown alga as a raw material for the production of bioethanol, the necessary the first step is a saccharification process, i.e., an enzymatic degradation of polysaccharides such as laminarin. As the second step, glucose produced by a laminarinase is fermented with the yeast. Notably, Motone et al. created a yeast with laminarinase by cell surface engineering [11]. Hydrolysis with an enzyme is often applied for the construction of a multiple parallel fermentation system for the brewing of sake, but there are few reports about the application of enzyme immobilization in such a system.

Methods of enzyme immobilization can be divided into carrier-bound technology, which is anchoring between a solid support (the carrier) and the enzyme, and other methods; e.g., entrapment, and cross-linking [12] [13] [14]. Solid support can be divided into organic polymers and inorganic polymers (e.g., silica, glass). Organic polymers can be sub-divided into natural polymers (e.g., cellulose, alginate, collagen, carbon) and synthetic polymers (e.g., polystyrene, polyacrylic, polypropylene) [12] [13] [14]. The carriers used for enzyme immobilization have one or more kinds of functional group (e.g., epoxy group, 
amino group, carboxylic acid), and are linked enzymatic protein by its functional group [12] [13]. Many types of immobilization beads are currently available on the market [13]. Various types of enzymes such as lipase, penicillin acylase, laccase and glucose isomerase have been applied in many industries with the use of immobilization [15] [16] [17]. There are also several reports on the immobilization of polysaccharide-degrading enzymes such as alpha-amylase [18], cellulose [19], and laminarinase [20]. From a cost-effectiveness viewpoint, both alphaamylase and cellulose are cheap and there is little need for their repeated use. In contrast, the cost of laminarinase is very high and its immobilization is thought to be a useful method.

In the present study, a novel $\beta$-1,3-glucanase from Flavobacterium sp. strain UMI-01, which had been isolated from decayed brown algae [21], was enzymatically characterized with laminarin as the substrate and we named it ULam111. We then assessed the activity and operational stability of the immobilized laminarinase ULam111 using many types of carrier. We also carried out a continuous saccharification of laminarin using immobilized ULam111 and examined ethanol fermentation from the saccharified solution with the marine-derived yeast.

\section{Materials and Methods}

\subsection{Materials}

L. digitata laminarin was purchased from Sigma-Aldrich (St. Louis, MO, USA), and E. bicyclis laminarin was from Tokyo Chemical Industry (Tokyo). We purchased the laminari-oligosaccharides: laminaribiose (L2), laminaritriose (L3), laminaritetraose (L4), laminaripentose (L5) and laminarihexsose (L6) from Megazyme (Bray, Ireland). The immobead enzyme carrier kit was purchased from ChiralVision (Leiden, The Netherlands).

\subsection{Construction of Recombinant ULam111 Expression System}

Genomic DNA from Flavobacterium sp. strain UMI-01 was prepared using ISOHAIR (Nippon Gene, Tokyo) as described [22]. A DNA encoding ULam111 (GenBank accession no. LC202090) was amplified by genomic polymerase chain reaction (PCR) using Q5 High-Fidelity DNA Polymerase (New England Biolabs, Ipswich, MA) with a primer set of F1

(5'-AGGTAATACACCATGACTAAAGGAAAAAAACTCGGT-3') and R1 (5'-CACCTCCACCGGATCCTTGATACACCTTAATATAGTC-3'). The thermal cycling conditions were: initial denaturation at $98^{\circ} \mathrm{C}$ for $30 \mathrm{sec}, 30$ cycles of denaturation at $98^{\circ} \mathrm{C}$ for $10 \mathrm{sec}$, annealing at $55^{\circ} \mathrm{C}$ for $15 \mathrm{sec}$, and extension at $72^{\circ} \mathrm{C}$ for $45 \mathrm{sec}$. Amplified DNA was ligated into a modified pCold vector (Takara, Shiga, Japan), which has been reported [23], using the In-Fusion HD Cloning Kit (Takara). After a sequencing analysis, recombinant plasmid DNA was introduced to E. coli BL21 (DE3) (Nippon Gene) or E. coli Rosetta-gami $^{\text {tw }} 2$ cells (Novagen, Darmstadt, Germany). 


\subsection{Expression and Purification of ULam 111}

(i) For the determination of the enzymatic properties of ULam111

E. coli BL21 (DE3) transformants were cultured at $37^{\circ} \mathrm{C}$ for $16 \mathrm{hr}$ in $\mathrm{LB}$ medium supplemented with $50 \mu \mathrm{g} / \mathrm{mL}$ ampicillin. After incubation at $15^{\circ} \mathrm{C}$ for $1 \mathrm{hr}$, isopropyl- $\beta$-D-thiogalactopyranoside (IPTG) was added for a final concentration of $0.1 \mathrm{mM}$, and the medium was cultured at $15^{\circ} \mathrm{C}$ for $12 \mathrm{hr}$. All subsequent steps were carried out at $4^{\circ} \mathrm{C}$ unless otherwise noted. Cells were harvested by centrifugation at $5000 \mathrm{~g}$ for $15 \mathrm{~min}$ and sonicated with a buffer containing 10 $\mathrm{mM}$ sodium phosphate buffer ( $\mathrm{pH} 8.0$ ), $0.5 \mathrm{M} \mathrm{NaCl}, 1 \%$ Triton $\mathrm{X}-100$, and 0.01 $\mathrm{mg} / \mathrm{mL}$ lysozyme. Supernatants after centrifugation at $10,000 \mathrm{~g}$ for $15 \mathrm{~min}$ were mixed with $200 \mu \mathrm{L}$ of TALON Cobalt Resins (Takara) and incubated for $30 \mathrm{~min}$. Resins were collected by centrifugation at $1500 \mathrm{~g}$ for $5 \mathrm{~min}$ and were washed with a buffer containing $20 \mathrm{mM}$ imidazole- $\mathrm{HCl}(\mathrm{pH} \mathrm{8.0)}$ and $\mathrm{NaCl}$. Protein elution was conducted with a buffer containing $150 \mathrm{mM}$ imidazole- $\mathrm{HCl}(\mathrm{pH}$ 8.0) and $\mathrm{NaCl}$. After sodium dodecyl sulfate-polyacrylamide gel electrophoresis (SDS-PAGE), fractions containing ULam111 were dialyzed against $10 \mathrm{mM}$ sodium phosphate buffer ( $\mathrm{pH}$ 6.0) and $100 \mathrm{mM} \mathrm{NaCl}$. The presence of the purified protein was confirmed by $10 \%$ (v/v) SDS-PAGE [24] with Coomassie Brilliant Blue R-250 dye. The protein concentration was determined by the Lowry method [25] using a DC Protein assay kit with bovine serum albumin (BSA) (Bio-Rad, Carlsbad, CA) as the standard.

(ii) For the immobilization of ULam 111

For the overexpression of ULam111, we grew E. coli Rosetta-gami ${ }^{\text {rm }} 2$ transformants in $\mathrm{LB}$ medium containing $50 \mu \mathrm{g} / \mathrm{mL}$ ampicillin at $37^{\circ} \mathrm{C}$. The expression of the ULam111 gene was induced by cold shock with shaking in water and ice until the temperature of a culture solution decreased to below $15^{\circ} \mathrm{C}$ and the addition of $1 \mathrm{mM}$ IPTG to the medium. After a further incubation at $15^{\circ} \mathrm{C}$ overnight, the cell pellet was collected by centrifugation, suspended in $50 \mathrm{mM}$ potassium phosphate buffer ( $\mathrm{pH} 7.5$ ), disrupted by sonication, and centrifuged twice at $20,000 \mathrm{~g}$ for $30 \mathrm{~min}$ at $4^{\circ} \mathrm{C}$. The resulting supernatant was applied to a $\mathrm{Ni} \mathrm{Se}-$ pharose $^{\mathrm{TM}}$ affinity column (GE Healthcare, Buckinghamshire, UK) $(30 \times 10 \mathrm{~mm})$ and eluted in a stepwise manner with $8 \mathrm{~mL}$ of $25 \mathrm{mM}, 75 \mathrm{mM}$ and $200 \mathrm{mM}$ imidazole in $50 \mathrm{mM}$ potassium phosphate buffer ( $\mathrm{pH} \mathrm{7.5)}$ and $0.5 \mathrm{M} \mathrm{NaCl}$. The fractions containing ULam 111 were concentrated using an Amicon Ultra device (Millipore, Bedford, MA) and dialyzed in $10 \mathrm{mM}$ sodium phosphate buffer ( $\mathrm{pH}$ 6.0), and ULam111 was thus partially purified.

\subsection{Enzyme Immobilization for Bead Screening}

For the screening of immobilization beads, we mixed $200 \mu \mathrm{L}$ of ULam111 (1.12 unit) with $50 \mathrm{mg}$ of each type of beads in $10 \mathrm{mM}$ sodium phosphate buffer ( $\mathrm{pH}$ 6.0) and incubated the mixture at $4^{\circ} \mathrm{C}$ overnight. After the incubation, the supernatant was removed and unbound protein was washed away three times with $0.5 \mathrm{~mL}$ of the same buffer. 


\subsection{The Measurement of $\beta-1,3-$ Glucanase Activity for the Determination of the Enzymatic Properties of ULam111}

The enzyme reaction was carried out in a solution containing $10 \mathrm{mM}$ sodium phosphate buffer ( $\mathrm{pH} 6.0$ ), $0.1 \mathrm{M} \mathrm{NaCl}, 0.1 \mathrm{mg} / \mathrm{mL} \mathrm{BSA}, 2.0 \mathrm{mg} / \mathrm{mL}$ laminarin from L. digitata, and $0.001 \mathrm{mg} / \mathrm{mL}$ ULam 111 at $30^{\circ} \mathrm{C}$ for 15 min unless otherwise stated. The degradation activity was determined by measuring the liberated sugar by the method of Prado et al. (1998) [26]. One unit was defined as the amount of the enzyme that releases $1 \mu \mathrm{mol}$ of glucose per min.

\subsection{The Laminarin-Degradingenzyme Assay for Immobilized ULam111}

Unless otherwise stated, the standard assay was carried out at $40^{\circ} \mathrm{C}$, using $10 \mathrm{~mL}$ of $1.5 \mathrm{mg} / \mathrm{mL}$ laminarin from E. bicyclis in $10 \mathrm{mM}$ sodium phosphate buffer $(\mathrm{pH}$ 6.0). After the reaction was stopped by heat treatment at $100^{\circ} \mathrm{C}$ for $10 \mathrm{~min}$, we determined the amount of reducing sugars by absorbance at $660 \mathrm{~nm}$ using the method of Somogyi-Nelson [27] [28] with glucose as a standard. One unit of activity is defined as the amount of enzyme required to release $1 \mu \mathrm{mol}$ glucose equivalent/min under the reaction conditions described above. The amount of glucose was determined using the F-kit D-glucose (JK-International, Tokyo).

\subsection{The Analysis of Laminari-Oligosaccharides by Thin-Layer Chromatography (TLC)}

Laminari-oligosaccharides produced by the ULam111 were analyzed by thinlayer chromatography (TLC). The oligosaccharides were developed on a TLC-60 plate (Merck, Darmstadt, Germany) with a solvent consisting of 1-butanol/ acetic acid/water or ethyl acetate/acetic acid/water (2:2:1, v:v:v) and detected by spraying $10 \%(\mathrm{v} / \mathrm{v})$ sulfuric acid in ethanol, followed by heating at $110^{\circ} \mathrm{C}-130^{\circ} \mathrm{C}$ for 5 - $10 \mathrm{~min}$.

\subsection{The Continuous Saccharification of Laminarin by the Recirculation Batch Method}

We performed the continuous saccharification of laminarin from E. bicyclis by the recirculation batch method [29]. To immobilize laminarinase, we mixed 2.0 $\mathrm{mL}$ of ULam111 (36 unit) with $500 \mathrm{mg}$ of the beads in $10 \mathrm{mM}$ sodium phosphate buffer ( $\mathrm{pH}$ 6.0) and incubated the mixture at $4^{\circ} \mathrm{C}$ overnight. After the incubation, the supernatant was removed and unbound protein was washed away with $50 \mathrm{~mL}$ of the same buffer. These experimental procedures were performed using an empty column (Econo-Column ${ }^{\circ} ; 185 \times 18 \mathrm{~mm}$; Bio-Rad). The column containing ULam111-immobilized beads was equipped with a bottle that contained $100 \mathrm{~mL}$ of $30 \mathrm{mg} / \mathrm{mL}$ laminarin solution added to $50 \mu \mathrm{g} / \mathrm{mL}$ ampicillin. The laminarin digestion reaction was performed at $30^{\circ} \mathrm{C}$ for $20 \mathrm{hr}$ while the laminarin solution was circulated by a peristaltic pump at $3.3 \mathrm{~mL} / \mathrm{min}$. After $20 \mathrm{hr}$, the

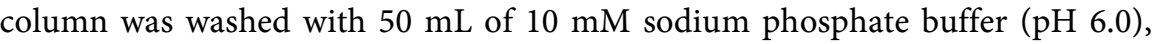
equipped with a new bottle containing $100 \mathrm{~mL}$ of $30 \mathrm{mg} / \mathrm{mL}$ laminarin solution, and used for a second time. The above process was repeated 10 times. 


\subsection{Ethanol Fermentation}

The ethanol fermentation was carried out by using Saccharomyces cerevisiae strain C-19, which was isolated from coastal water from Tokyo Bay in Japan [30]. The C-19 was incubated in $10 \mathrm{~mL}$ of $30 \mathrm{mg} / \mathrm{mL}$ laminarin solution digested by the immobilization reactor under anaerobic conditions at room temperature for 1 day. After the yeasts were removed by centrifugation, the amounts of ethanol were analyzed using an LC-20 HPLC system (Shimadzu, Kyoto, Japan) equipped with a refractive index detector (RID-10A; Shimadzu) through a Shim-pack SPR$\mathrm{Pb}$ column $(250 \times 7.8 \mathrm{~mm}$; Shimadzu $)$ at $80^{\circ} \mathrm{C}$ in distilled water at $0.6 \mathrm{~mL} / \mathrm{min}$.

\subsection{Technical Terms and the Data Processing Methods}

Efficient immobilization of ULam111 for carrier materials was evaluated according to following the equations and terminology in reference [14]: "Immobilization yield" (\%) $=100 \times$ ("immobilized activity"/"starting activity"), "Immobilization efficiency" (\%) = $100 \times$ ("observed activity"/ "immobilized" activity), "Activity recovery" (\%) = $100 \times$ ("observed activity"/"starting activity"). The "immobilized activity" was determined by measuring the total residual enzyme activity that remains in the enzyme solution after immobilization and by subtracting this activity from the total "starting activity" (enzyme activity before immobilization). The "observed activity" was determined by measuring the activity of immobilized beads. Ethanol productivity (E.P.) was defined as follows: E.P. $=($ real ethanol production/ideal ethanol production $) \times 100(\%)$ [31]

\section{Results and Discussion}

\subsection{The Enzymatic Properties of ULam111}

A gene (ulam111) encoding $\beta$-1,3-glucanase-like protein, which consists of 753 bp, was found on the Flavobacterium sp. strain UMI-01 draft genome sequence. According to our BLAST search [32], the deduced amino acid sequence of ULam111 showed significant identity with other $\beta$-1,3-glucanases belonging to the GH16 family. As shown in Figure 1, the amino acid sequence of ULam111 had the highest identity (70\%) with that of Flavobacterium sp. ACAM 123 laminarinase and relative high identity with a Flavobacterium sp. 4221 GH16 family precursor (68\%) [33], Cellulophaga algicola DSM 14237 glucan endo-1,3-betaD-glucosidase (57\%) [34], a Pedobacter sp. 4236 GH16 family precursor (37\%) [33], and Lysobacter enzymogenes strain N4-7 beta-1,3-glucanase A (33\%) [35].

The proposed catalytic residues [37] Glu134 and Glu139 were conserved in ULam 111 and the proteins listed in Figure 1. Since N-terminal 17 residues were predicted as a secretion signal peptide by the SignalP program [38], residues 18 251 of ULam111 were expressed as a recombinant protein (ULam111) with octahistidine-tag at C-terminus. ULam111 was successfully expressed and purified with the yield of $0.6 \mathrm{mg}$ from $1 \mathrm{~L}$ of culture medium (Figure 2).

We examined the enzymatic properties of ULam111 using laminarin from $L$. digitata. Purified ULam111 showed degradation activity against laminarin with the specific activity of $224 \pm 18 \mathrm{U} / \mathrm{mg}$ at $30^{\circ} \mathrm{C}, \mathrm{pH}$ 6.0. Its optimum temperature 


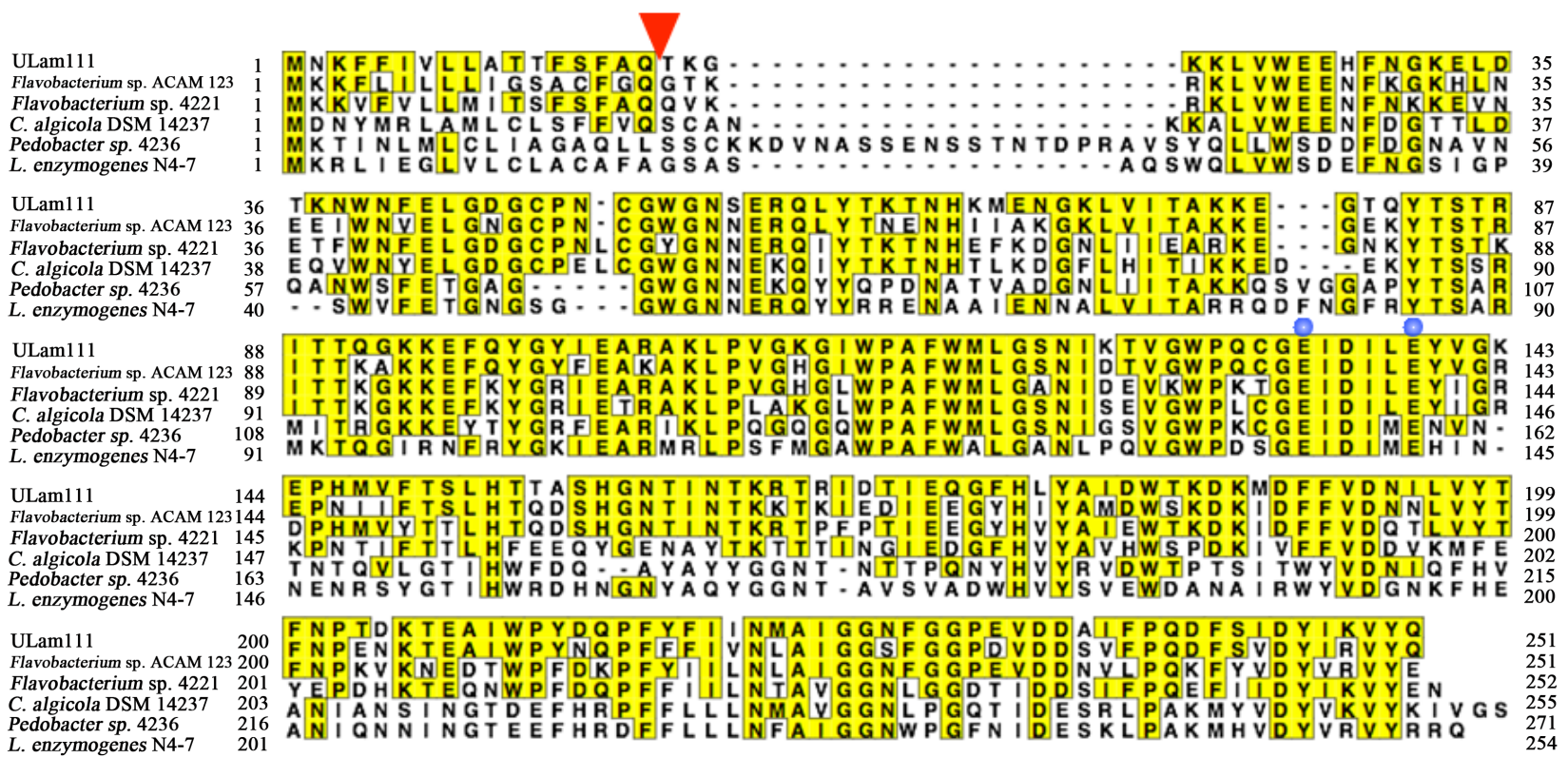

Figure 1. Multiple alignment between ULam111 and the homologous proteins. ULam111, Flavobacterium sp. UMI-01 candidate $\beta$-1,3-glucanase (in this study); Flavobacterium sp. ACAM 123, Flavobacterium sp. ACAM 123 laminarinase (GenBankacc.no. WP_ 016988671); Flavobacterium sp. 4221, Flavobacterium sp. 4221 GH16 precursor (GenBankacc.no. ABW02990, [33]); C. algicola DSM 14237, Cellulophaga algicola DSM 14237 glucan endo-1,3-beta-D-glucosidase (GenBankacc.no.YP_004163306, [34]); Pedobacter sp. 4236, Pedobacter sp. 4236 GH16 precursor (GenBankacc.no. ABW02990, [33]); L. enzymogenes strain N4-7, Lysobacter enzymogenes strain N4-7 beta-1,3-glucanase A (GenBankacc.no. AY157838, [35]). The amino acid sequences were aligned using the Clustal W program [36]. The red inverted triangle indicates a putative signal peptide cleavage site. The blue circles show putative catalytic residues.

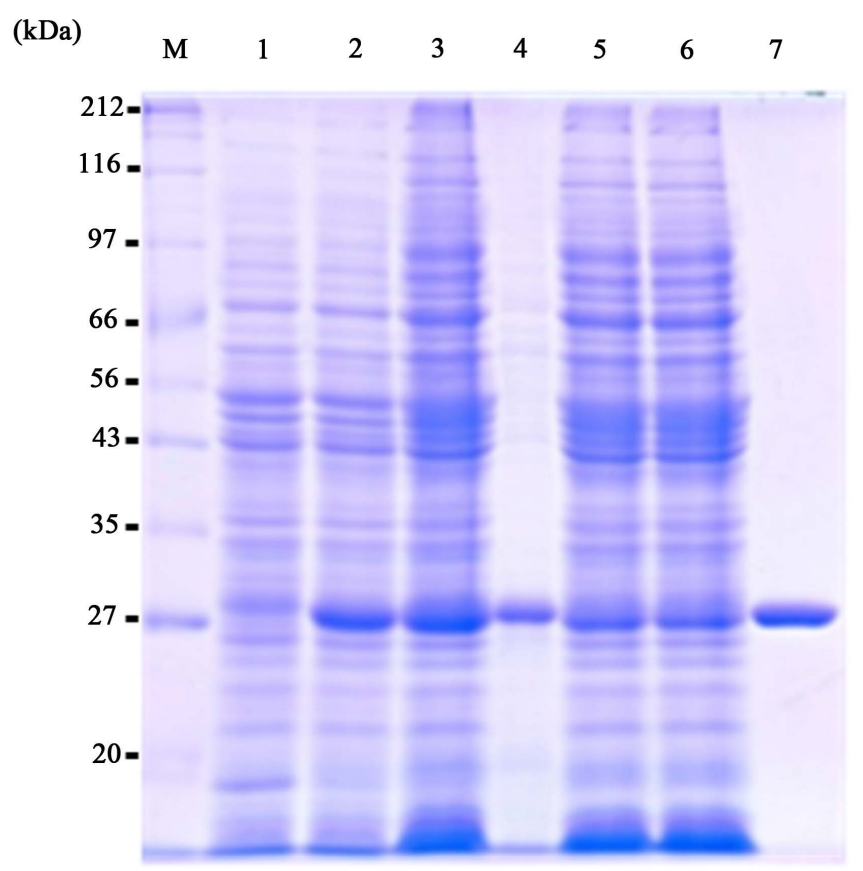

Figure 2. Bacterial expression and purification of recombinant ULam111. M; protein molecular marker, lane 1 and lane 2; cell extracts before and after induction by IPTG, respectively, lane 3; total cell extracts homogenized with a buffer containing lysozyme, lane 4 and lane 5; precipitates and supernatant after centrifugation of total fraction, respectively, lane 6; unbound fraction with resin, lane 7; purified ULam111. 
was $50^{\circ} \mathrm{C}$, and degradation activities were observed at $4^{\circ} \mathrm{C}-80^{\circ} \mathrm{C}$ (Figure $3(\mathrm{a})$ ). Heat stability was investigated by incubation for $30 \mathrm{~min}$ at various temperatures. The remaining activity was significantly decreased by the incubation above $50^{\circ} \mathrm{C}$, and a $50 \%$ loss of activity was observed at $46^{\circ} \mathrm{C}$ (Figure $3(\mathrm{~b})$ ). The $\mathrm{NaCl}$ concentration did not have a detectable effect on the activity. The highest activity was observed at $125 \mathrm{mMNaCl}$, but $72 \%$ - 78\% maximal activities were measured at $500-1000 \mathrm{mMNaCl}$ (Figure 3(c)). As shown in Figure 3(d), ULam111 preferred acidic conditions. Although its optimum $\mathrm{pH}$ was around 6.0, there was no activity under $\mathrm{pH} 4.0$ (Figure $3(\mathrm{~d})$ ).

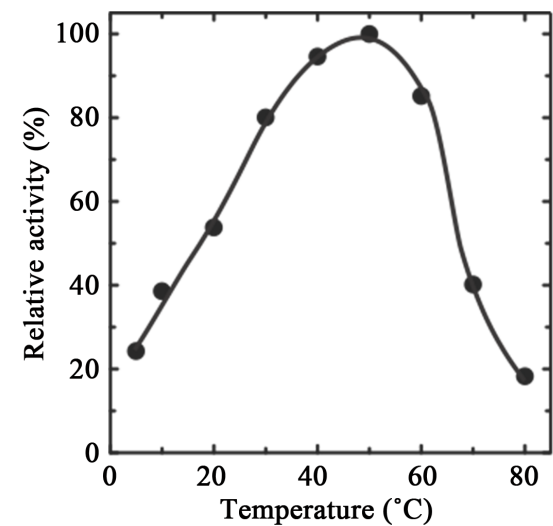

(a)

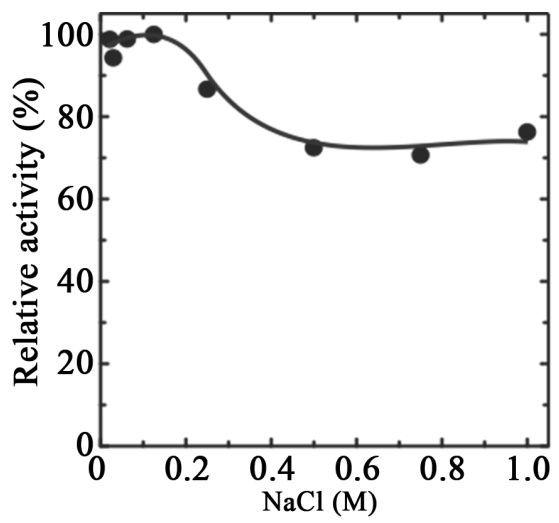

(c)

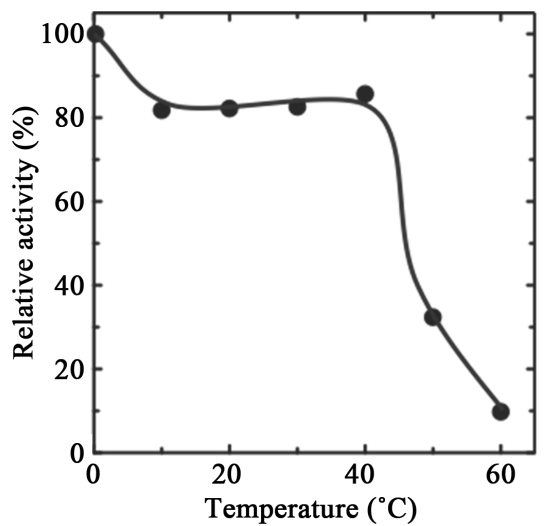

(b)

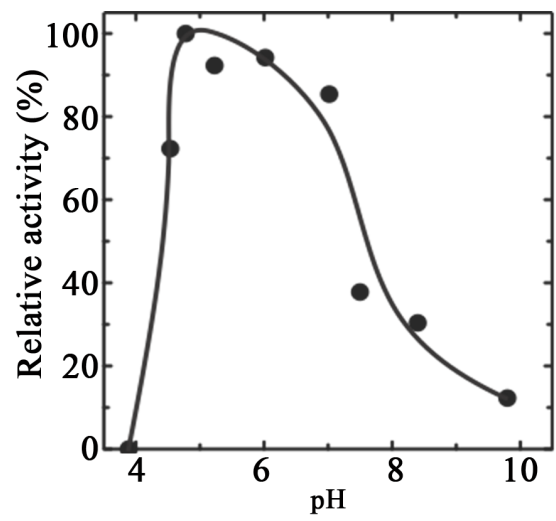

(d)

Figure 3. Effects of temperature, $\mathrm{pH}$ and $\mathrm{NaCl}$ concentration. (a) The enzyme reaction was carried out in a solution containing $10 \mathrm{mM}$ sodium phosphate buffer ( $\mathrm{pH} 6.0$ ), $0.1 \mathrm{M}$ $\mathrm{NaCl}, 0.1 \mathrm{mg} / \mathrm{mL} \mathrm{BSA}, 2.0 \mathrm{mg} / \mathrm{mL}$ laminarin, and $0.001 \mathrm{mg} / \mathrm{mL}$ ULam 111 at the indicated temperature for $15 \mathrm{~min}$; (b) enzyme solution was pre-incubated at the indicated temperature for $30 \mathrm{~min}$. The reaction was then carried out in a solution containing 10 $\mathrm{mM}$ sodium phosphate buffer ( $\mathrm{pH} 6.0$ ), $0.1 \mathrm{M} \mathrm{NaCl}, 0.1 \mathrm{mg} / \mathrm{mL} \mathrm{BSA}, 2 \mathrm{mg} / \mathrm{mL}$ laminarin, and $0.001 \mathrm{mg} / \mathrm{mL}$ ULam 111 at $30^{\circ} \mathrm{C}$ for $15 \mathrm{~min}$; (c) the enzyme reaction was carried out in a solution containing $10 \mathrm{mM}$ sodium phosphate buffer ( $\mathrm{pH} 6.0$ ), $0.02-1.0 \mathrm{M} \mathrm{NaCl}$, $0.1 \mathrm{mg} / \mathrm{mL}$ BSA, $2.0 \mathrm{mg} / \mathrm{mL}$ laminarin, and $0.001 \mathrm{mg} / \mathrm{mL}$ ULam 111 at the indicated temperature for $15 \mathrm{~min}$; (d) the enzyme reaction was carried out in a solution containing 0.1 $\mathrm{M} \mathrm{NaCl}, 0.1 \mathrm{mg} / \mathrm{mL} \mathrm{BSA}, 2.0 \mathrm{mg} / \mathrm{mL}$ laminarin, and $0.001 \mathrm{mg} / \mathrm{mL}$ ULam111 at the indicated $\mathrm{pH}$ values $(10 \mathrm{mM} \mathrm{CH} 3 \mathrm{COONa}$ for $\mathrm{pH} 3.8-5.2,10 \mathrm{mM}$ sodium phosphate buffer for $\mathrm{pH} 6.0-7.4,10 \mathrm{mM}$ Tris- $\mathrm{HCl}$ for $\mathrm{pH} 8.3,10 \mathrm{mM}$ glycine- $\mathrm{NaOH}$ for $\mathrm{pH} 9.8$ ) at $30^{\circ} \mathrm{C}$ for $15 \mathrm{~min}$. 
The degradation products of laminarin by ULam111 were sequentially analyzed by TLC (Figure 4(a)). After 2 min of reaction, glucose and oligosaccharides were detected. The levels of glucose and laminaribiose increased and were identified as major products after $48 \mathrm{hr}$. Interestingly, a spot showing abnormal mobility between laminaritriose and laminaritetraose appeared after $1 \mathrm{hr}$. This product may contain not only $\beta$-1,3-bonds but $\beta$-1,6-bonds because laminarin from $L$. digitata contains $\beta-1,3$ and $\beta-1,6$ glycosidic bonds at the ratio of 7:1 [5].

We also investigated the degradation of various laminarioligosaccharides by ULam111. Among the tested oligosaccharides, only laminaribiose was undegradable (Figure 4(b)). Laminaritriose, laminaritetraose, and laminaripentaose were each degraded, and the main products were glucose and laminaribiose in each case (Figure 4(b)). Thus, trisaccharide was the minimum length for the hydrolysis of ULam 111 .

Next, the yield of glucose from laminarin by ULam111 was measured (Figure 5). The glucose concentration in a mixture containing $5.0 \mathrm{mg} / \mathrm{mL}$ laminarin at the start of the reaction reached a maximum at $2.5 \mathrm{mg} / \mathrm{mL}$ after $10 \mathrm{hr}$. Thus, laminarin was converted to glucose by ULam 111 with $50 \%$ efficiency.

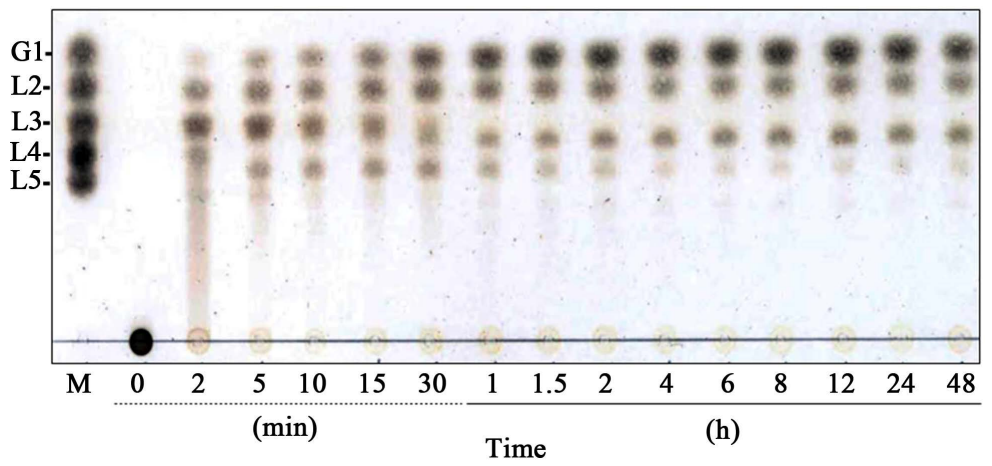

(a)

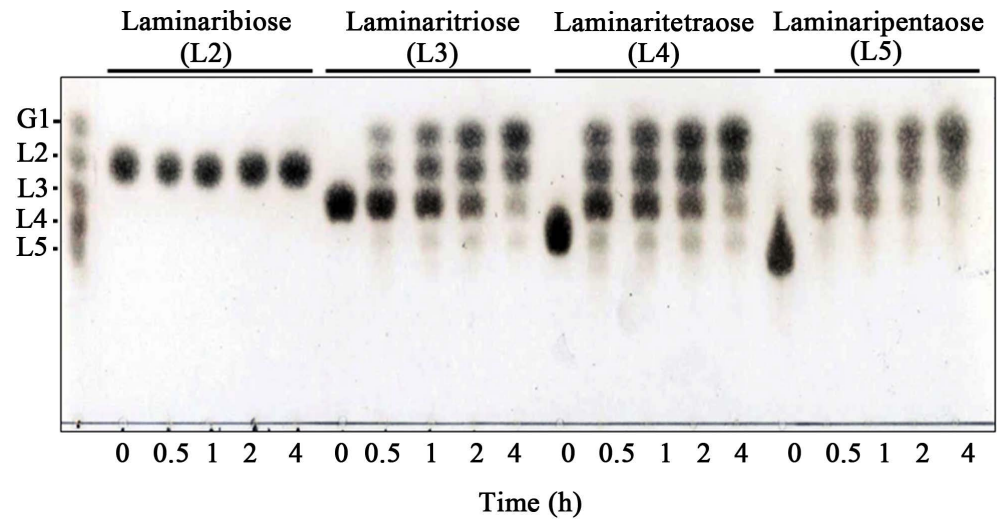

(b)

Figure 4. TLC analysis. (a) The mode of action for laminarin degradation by ULam111. The enzyme reaction was carried out in a solution containing $10 \mathrm{mM}$ sodium phosphate buffer (pH 6.0), $0.1 \mathrm{M} \mathrm{NaCl}, 0.1 \mathrm{mg} / \mathrm{mL} \mathrm{BSA}, 2.0 \mathrm{mg} / \mathrm{mL}$ laminarin, and $0.02 \mathrm{mg} / \mathrm{mL}$ ULam111-full (residues 1 - 251) or $0.001 \mathrm{mg} / \mathrm{mL}$ ULam 111 at $30^{\circ} \mathrm{C}$, and then stopped at each indicated time by heating in boiling water for $10 \mathrm{~min}$; (b) Degradation of laminarioligosaccharides by ULam 111 . 


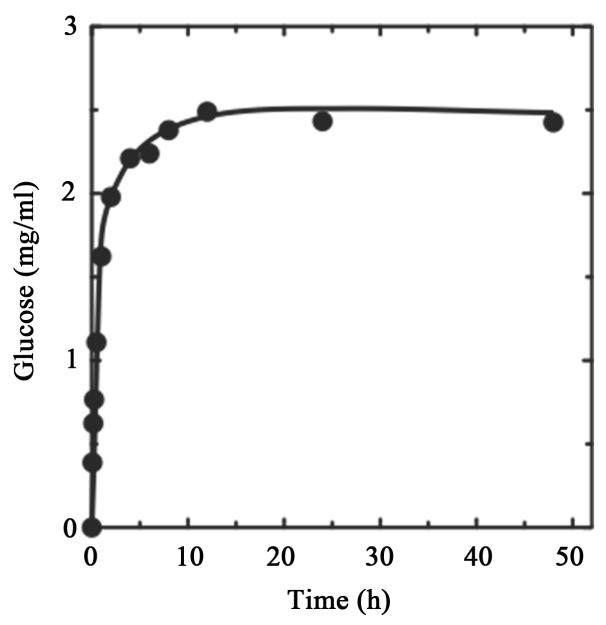

Figure 5. The amount of glucose produced by ULam111 from laminarin. The reaction was carried out in a solution containing $10 \mathrm{mM}$ sodium phosphate buffer ( $\mathrm{pH} 6.0$ ), $0.1 \mathrm{M}$ $\mathrm{NaCl}, 0.1 \mathrm{mg} / \mathrm{mL}$ BSA, $0.01 \mathrm{mg} / \mathrm{mL}$ ULam 111 , and $5.0 \mathrm{mg} / \mathrm{mL}$ laminarin at $30^{\circ} \mathrm{C}$. The amount of glucose was determined using the F-kit D-glucose (JK-International, Tokyo).

\subsection{The Selection of Immobilization Beads for ULam111}

To select immobilization beads suitable for ULam111 by a first screening, we investigated the "immobilization yield", "immobilization efficiency" and "activity recovery" when the 1.12 unit of laminarinase was immobilized with the use of the 11 types of commercially available immobilization beads (Table 1). First, to determine the percentage of protein bound to the immobilization beads (immobilization yield), we measured the enzyme activities in the supernatant after immobilization. Among the 11 types of immobilization beads, the seven types, i.e., IB-150P (the covalent type), IB-C435 (the cationic type), IB-A369 (the anionic type), IB-EC1, IB-S861, IB-S500, IB-S60P, and IB-S60S (the non-ionic type) showed $\geq 72.9 \%$ immobilization yield. Next, to identify the percentage of remaining enzyme activities of bound protein to immobilization beads (i.e., the immobilization efficiency), we measured the enzyme activities of the immobilized beads. The highest values of immobilization efficiency, were obtained with IB-S60P (the non-ionic type) at $26.6 \%$, along with $15.6 \%$ for IB-S60S (the non-ionic type), $13.6 \%$ for IB-150P (the covalent type) and $7.71 \%$ for IB-C435 (the cationic type). Finally, we investigated the percentage of remaining enzyme activities in the immobilization beads of total protein used for the immobilization (i.e., the activity recovery). The values were as follows: the highest values were $19.4 \%$ for IB-S60P (the non-ionic type), $15.6 \%$ for IB-S60S (the non-ionic type), $11.9 \%$ for IB-150P (the covalent type), and $7.1 \%$ for IB-C435 (the cationic type). We thus selected these four types of beads in the first screening.

To assess the operational stability of immobilized ULam111 on these types of four beads, we performed a sixth repeat of the batch experiments with $50 \mathrm{mg}$ beads immobilizing 1.12 units of laminarinase at $30^{\circ} \mathrm{C}$ for $30 \mathrm{~min}$. As shown in Figure 6, for the non-ionic types IB-S60S and IB-S60P, the "observed activities" of the beads remained at $43.4 \%$ and $27.8 \%$, respectively of the first time during the sixth cycle. In contrast, for the covalent-type IB-150P beads and the cationic- 
Table 1. Immobilization evaluation of ULam111 for different carrier materials.

\begin{tabular}{|c|c|c|c|c|c|c|c|c|}
\hline $\begin{array}{l}\text { Product } \\
\text { Name }\end{array}$ & Type & Matrix & $\begin{array}{l}\text { Functional } \\
\text { group }\end{array}$ & $\begin{array}{l}\text { Observed } \\
\text { activity }^{\mathrm{a}} \\
\text { (U) }\end{array}$ & $\begin{array}{c}\text { Activity in } \\
\text { supernatant }^{\mathrm{a}} \\
\text { (U) }\end{array}$ & $\begin{array}{c}\text { Immobilization } \\
\text { Yield } \\
(\%)\end{array}$ & $\begin{array}{c}\text { Immobilization } \\
\text { Efficiency } \\
(\%)\end{array}$ & $\begin{array}{c}\text { Activity } \\
\text { recovery } \\
(\%)\end{array}$ \\
\hline IB-150P & covalent & polyacrylic & epoxide, polar & $0.134 \pm 0.025$ & $0.137 \pm 0.003$ & 87.7 & 13.6 & 11.9 \\
\hline IB-D152 & cationic & polyacrylic & carboxylic acid & $0.001 \pm 0.001$ & $0.539 \pm 0.069$ & 51.8 & 0.2 & 0.1 \\
\hline IB-C435 & cationic & polyacryic & carboxylic acid & $0.079 \pm 0.005$ & $0.091 \pm 0.006$ & 91.8 & 7.7 & 7.1 \\
\hline IB-A161 & anionic, strong & polystyrene & quat. Ammon & 0 & 0.738 & 34.1 & 0 & 0 \\
\hline IB-A171 & anionic, strong & polystyrene & quat. Ammon & 0 & 0.704 & 37.1 & 0 & 0 \\
\hline IB-A369 & anionic, weak & polystyren & quat. Ammon & 0 & 0.082 & 92.9 & 0 & 0 \\
\hline IB-EC1 & non-ionic & polyacryic & carboxylic ester & 0 & 0.286 & 74.5 & 0 & 0 \\
\hline IB-S861 & non-ionic & polystyrene & aromatic & 0 & 0.118 & 89.1 & 0 & 0 \\
\hline IB-S500 & non-ionic & polypropylene & alkyl & 0 & 0.146 & 86.7 & 0 & 0 \\
\hline IB-S60P & non-ionic & silica, porous & hydroyl & $0.217 \pm 0.007$ & $0.304 \pm 0.011$ & 72.9 & 26.6 & 19.4 \\
\hline IB-S60S & non-ionic & $\begin{array}{l}\text { silica, super } \\
\text { porous }\end{array}$ & hydroyl & $0.174 \pm 0.029$ & 0 & 100 & 15.6 & 15.6 \\
\hline
\end{tabular}

${ }^{a}$ The reactions were carried out in triplicate except the enzymatic activity in supernatant of carrier beads showed no "observedactivity", and the data are mean \pm SD.

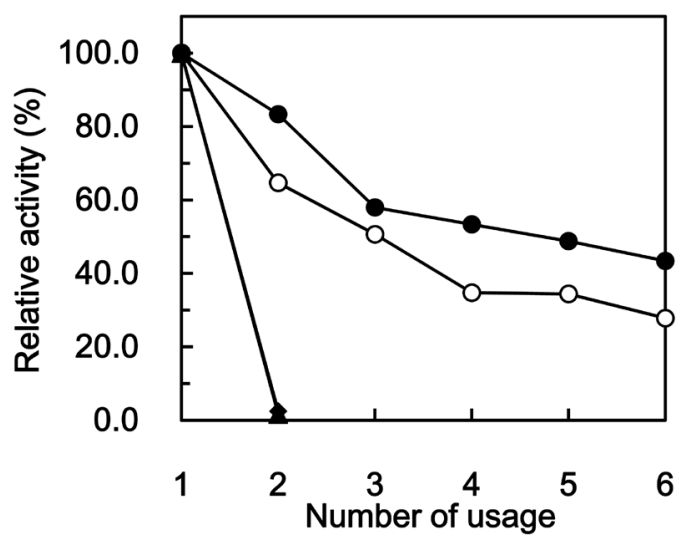

Figure 6. The relative activities of immobilized laminarinase. Each number of repetitions is shown by $\circ$ : IB-S60P (the non-ionic type), •: IB-S60S (the non-ionic type), $\bullet$ IB-150P (the covalent type), $\mathbf{\Delta}$ : IB-C435 (the cationic type). One hundred percent of activity corresponds to the "observed activity" of the first time for each carrier beads.

type IB-C435 beads, during the second repetition, no "observed activity" was detected.

We therefore selected IB-S60S beads for laminarinase from among the 11 types of commercially available immobilization beads as suitable beads. IB-S60S and IB-S60P beads are solid support of silica. The silica-binding peptide mediates the efficient immobilization of each enzyme onto mesoporous silica-based materials such as zeolite for thermostable hemicellulases: $\beta$-glucosidase, $\beta$-xylanase and $\beta$-mannanase [39]. Glycoside hydrolases including laminarinase often have non-catalytic carbohydrate-binding modules (CBMs) appended to the catalytic domain [40]. Several studies have used a CBM as an affinity tag for en- 
zyme immobilization to solid support made from carbohydrate, and in some instances, the enzymatic activity was increased [41]. If we could identify a linker adapted to ULam111 such as a silica-binding peptide, we may be able to increase the enzymatic activity of immobilized ULam 111.

\subsection{The Continuous Saccharification of Laminarin by Immobilized ULam111 Followed by Ethanol Fermentation}

For the saccharification of a large volume of laminarin solution, we constructed an experimental reactor system with immobilized ULam111 using the non-ionic type IB-S60S beads, as shown in Figure 7. In this reactor system, approx. 10 $18 \mathrm{~g} / \mathrm{L}$ glucose was produced from $30 \mathrm{mg} / \mathrm{mL}$ laminarin solutions after $20 \mathrm{hr}$, when the reactor operation was repeated 10 times (Figure 8(a)). When free laminarinase with an equal or one-tenth amount of immobilized enzyme was used in one trial, $23.2 \mathrm{~g} / \mathrm{L}$ or $13.0 \mathrm{~g} / \mathrm{L}$ of glucose was produced, respectively. Therefore, the immobilized laminarinase was found to retain sufficient activity during repeated trials in the reactor system.

To analyze the digestion product, we performed a TLC analysis of the saccharification product. As shown in Figure 8(b), the production of glucose was confirmed in 10 repetitions, but the amount of glucose gradually decreased. Spots of triose most strongly appeared. These spots also had abnormal mobility between laminaritriose and laminaritetraose. More interestingly, although ULam111 did not have the ability to digest laminaribiose (Figure 4(b)), laminaribiose (L2) was not detected. These products might have contained many trioses and may not have contained laminaribiose because laminarin from E. bicyclis has $\beta-1,6$ glycosidic bonds at very high rates $(\beta-1,3: \beta-1,6=3: 2)$ [6]. Therefore, providing hydrolysis enzymes that are capable of the digestion of $\beta$-1,6-linked glucose branches and laminaribiose may significantly improve the glucose yield.

We also measured the production of reducing sugars (Figure $8(\mathrm{c})$ ) and glucose (Figure $8(\mathrm{~d})$ ) over time. The glucose $1.2-1.9 \mathrm{~g} / \mathrm{L}$ was repeatedly produced from $30 \mathrm{mg} / \mathrm{mL}$ laminarin solutions after $20 \mathrm{hr}$ when the reactor was operated 10

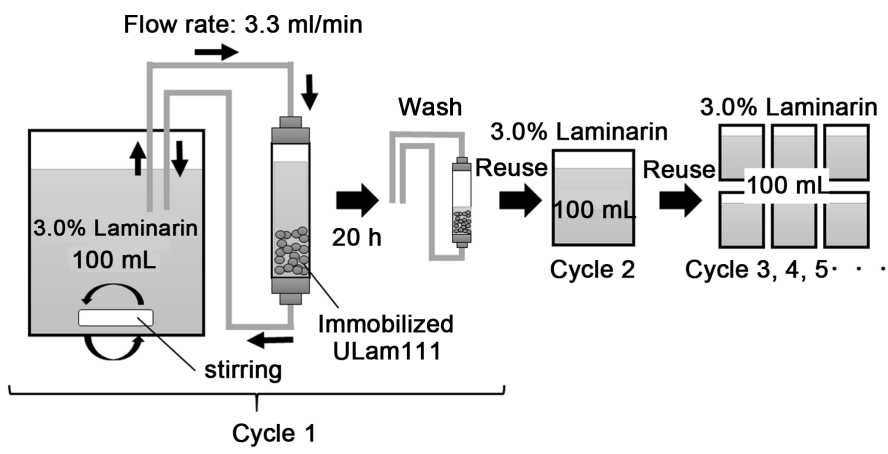

Figure 7. The schema of the experimental reactor system using immobilized laminarinase. The laminarin digestion reaction was performed at $30^{\circ} \mathrm{C}$ for $20 \mathrm{hr}$ while a laminarin solution was circulated by a peristaltic pump at $3.3 \mathrm{~mL} / \mathrm{min}$. After $20 \mathrm{hr}$, this column was washed with $50 \mathrm{~mL}$ of $10 \mathrm{mM}$ sodium phosphate buffer ( $\mathrm{pH} 6.0$ ), equipped with a new bottle containing $100 \mathrm{~mL}$ of $30 \mathrm{mg} / \mathrm{mL}$ laminarin solution, and used for the second time. The above process was repeated 10 times. 


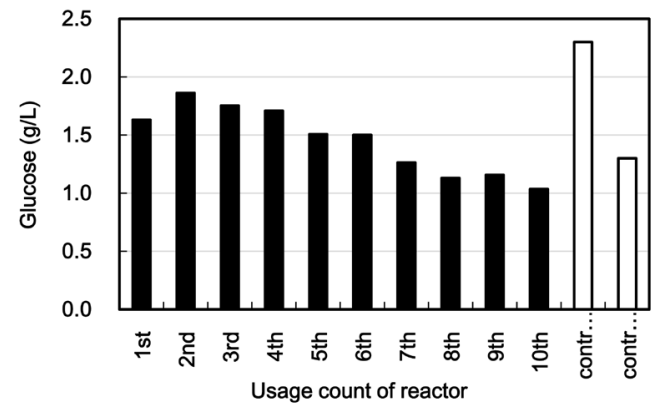

(a)
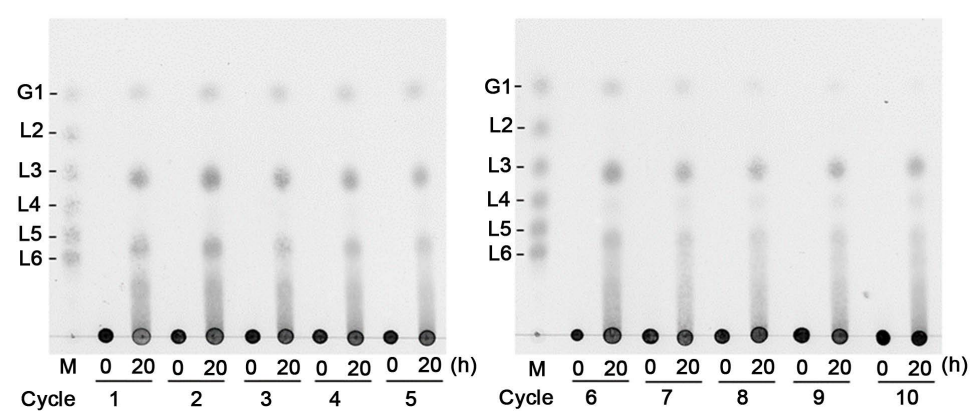

(b)

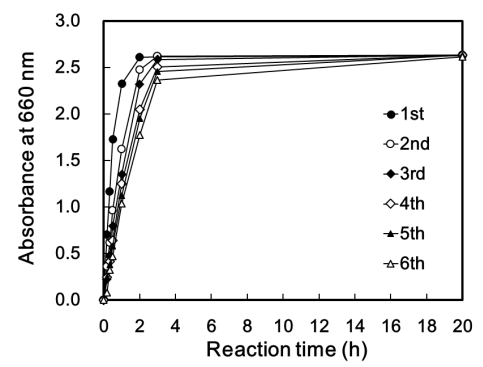

(c)

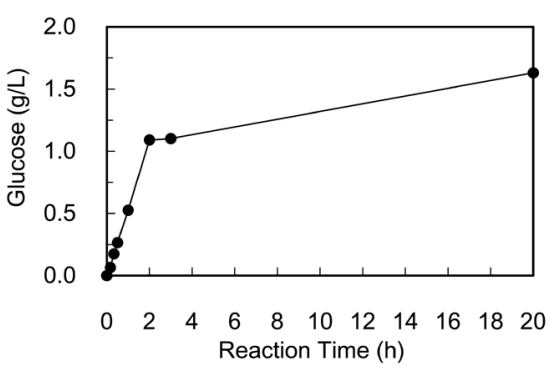

(d)

Figure 8. Continuous saccharification of laminarin by ULam111-immobilized IB-S60S beads. (a) The amount of glucose production by the experimental reactor system at each number of repetitions; (b) the TLC analysis of laminari-oligosaccharides by the experimental reactor system at each number of repetitions; (c) the production of reducing sugar over time by the experimental reactor system at each number of repetitions; (d) production of glucose overtime.

times. The production of reducing sugar was terminated for approx. $3 \mathrm{hr}$ and the amounts of reducing sugar were almost equal in the 10-times trials of the reactor. As shown in Figure 8(d), nearly 70\% of the glucose was produced within 2 hr reaction time. Our results thus demonstrated that most of the glucose and oligosaccharide was produced within 2 - $3 \mathrm{hr}$ using this reactor, but the glucose yield increased by using this reactor for a longer time.

Following the saccharification of laminarin by immobilized ULam111, we examined the ethanol fermentation using the second and fourth saccharified solutions of 10 -times saccharification. The results showed that $0.58 \mathrm{~g} / \mathrm{L}(60.1 \%$ of the theoretical value) and $0.51 \mathrm{~g} / \mathrm{L}(58.3 \%$ of the theoretical value) were produced from laminarin saccharified solutions that contained $1.86 \mathrm{~g} / \mathrm{L}$ and $1.71 \mathrm{~g} / \mathrm{L}$ of glucose for $20 \mathrm{hr}$, as shown in Table 2 . 
Table 2. Ethanol production from $30 \mathrm{mg} / \mathrm{mL}$ laminarin saccharified solutions by a marine-derived yeast $S$. cerevisiae C-19.

\begin{tabular}{cccc}
\hline No. of saccharified solutions $^{\mathrm{a}}$ & Glucose $^{\mathrm{b}}(\mathrm{g} / \mathrm{L})$ & Ethanol $(\mathrm{g} / \mathrm{L})$ & Ethanol productivity (\%) \\
\hline 2nd & 1.86 & 0.58 & 61.0 \\
4th & 1.71 & 0.51 & 58.3 \\
\hline
\end{tabular}

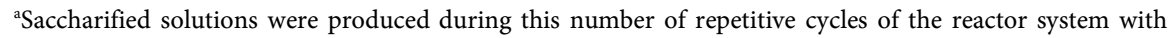

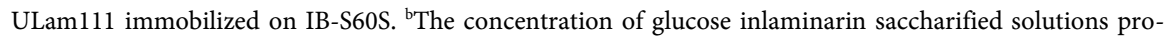
duced using the reactor system.

\section{Conclusion}

We investigated the continuous saccharification of laminarin by immobilized laminarinase ULam 111 followed by ethanol fermentation with a marine-derived yeast. The novel laminarinase ULam111 was isolated from Flavobacterium sp. UMI-01, and purified ULam111 showed degradation activity against laminarin with the specific activity of $224 \pm 18 \mathrm{U} / \mathrm{mg}$ at $30^{\circ} \mathrm{C}$ and $\mathrm{pH}$ 6.0. With the use of our reactor system with ULam111 immobilized on IB-S60S carrier beads, 1.2 $1.9 \mathrm{~g} / \mathrm{L}$ glucose was repeatedly produced from $30 \mathrm{mg} / \mathrm{mL}$ laminarin solutions after $20 \mathrm{hr}$ when the reactor was operated 10 times. Ethanol fermentation from the saccharified solutions with the marine-derived yeast $S$. cerevisiae C-19 was carried out, and $0.51-0.58 \mathrm{~g} / \mathrm{L}$ bioethanol was produced from the saccharified solution containing $1.71-1.86 \mathrm{~g} / \mathrm{L}$ of glucose.

\section{References}

[1] Nelson, T.E. and Lewis, B.A. (1974) Separation and Characterization of the Soluble and Insoluble Components of Insoluble Laminaran. Carbohydrate Research, 33, 63-74.

[2] Rioux, L.E., Turgeon, S.L. and Beaulieu, M. (2010) Structural Characterization of Laminaran and Galactofucan Extracted from the Brown Seaweed Saccharina longicruris. Phytochemistry, 71, 1586-1595.

[3] Chizhov, A.O., Dell, A., Morris, H.R., Reason, A.J., Haslam, S.M., McDowell, R.A., Chizhov, O.S. and Usov, A.I. (1998) Structural Analysis of Laminarans by MALDI and FAB Mass Spectrometry. Carbohydrate Research, 310, 203-210.

[4] Kadam, S.U., Tiwari, B.K. and O’Donnell, C.P. (2015) Extraction, Structure and Biofunctional Activities of Laminarin from Brown Algae. International Journal of Food Science \& Technology, 50, 24-31. https://doi.org/10.1111/ijfs.12692

[5] Bull, A.T. and Chesters, C.G.C. (1966) The Biochemistry of Laminarin and the Nature of Laminarinase. Advances in Enzymology, 28, 325-364.

[6] Usui, T., Toriyama, T. and Mizuno, T. (1979) Structural Investigation of Laminaran of Eisenia bicyclis. Agricultural and Biological Chemistry, 43, 603-611.

[7] Lombard, V., Golaconda Ramulu, H., Drula, E., Coutinho, P.M. and Henrissat, B. (2014) The Carbohydrate-Active Enzymes Database (CAZy) in 2013. Nucleic Acids Research, 42, D490-D495. https://doi.org/10.1093/nar/gkt1178

[8] Labourel, A., Jam, M., Jeudy, A., Hehemann, J.-H., Czjzek, M. and Michel, G. (2014) The $\beta$-Glucanase $Z g$ LamA from Zobellia galactanivorans Evolved a Bent Active Site Adapted for Efficient Degradation of Algal Laminarin. Journal of Biological Chemistry, 289, 2027-2042. https://doi.org/10.1074/jbc.M113.538843 
[9] Takagi, T., Uchida, M., Matsushima, R., Kodama, H., Takeda, T., Ishida, M. and Urano, N. (2015) Comparison of Ethanol Productivity among Yeast Strains Using Three Different Seaweeds. Fisheries Science, 81, 763-770. https://doi.org/10.1007/s12562-015-0875-6

[10] Takagi, T., Adachi, S., Higashi, M., Kawaguchi, R., Uchida, M., Matsushima, R., Ishida, M. and Urano, N. (2012) Bioethanol Production from Seaweeds Using Aquatic Yeasts. The 9th Asia-Pacific Marine Biotechnology Conference Oral Sec, 14S10-5.

[11] Motone, K., Takagi, T., Sasaki, Y., Kuroda, K. and Ueda, M. (2016) Direct Ethanol Fermentation of the Algal Storage Polysaccharide Laminarin with an Optimized Combination of Engineered Yeasts. Journal of Biotechnology, 231, 129-135.

[12] Brena, B.M. and Batista-Vier, F. (2006) Method in Biotechnology: Immobilization of Enzymes and Cells. 2nd Edition, Springer, Berlin.

[13] Cantone, S., Ferrario, V., Corici, L., Ebert, C., Fattor, D., Spizzo, P. and Gardossi, L. (2013) Efficient Immobilisation of Industrial Biocatalysts: Criteria and Constraints for the Selection of Organic Polymeric Carriers and Immobilisation Methods. Chemical Society Reviews, 42, 6262-6276. https://doi.org/10.1039/c3cs35464d

[14] Sheldon, R.A. and van Pelt, S. (2013) Enzyme Immobilisation in Biocatalysis: Why, What and How. Chemical Society Reviews, 42, 6223-6235. https://doi.org/10.1039/c3cs60075k

[15] Poulsen, P.B. (1984) Current Applications of Immobilized Enzymes for Manufacturing Purpose. Biotechnology \& Genetic Engineering Reviews, 1, 121-140. https://doi.org/10.1080/02648725.1984.10647783

[16] Khan, A.A. and Alzohairy, M.A. (2010) Recent Advances and Applications of Immobilized Enzyme Technologies: A Review. Research Journal of Biological Sciences, 5, 565-575. https://doi.org/10.3923/rjbsci.2010.565.575

[17] DiCosimo, R., McAuliffe, J., Poulose, A.J. and Bohlmann, G. (2013) Industrial Use of Immobilized Enzymes. Chemical Society Reviews, 42, 6437-6474. https://doi.org/10.1039/c3cs35506c

[18] He, L., Mao, Y., Zhang, L., Wang, H., Alias, S.A., Gao, B. and Wei, D. (2017) Functional Expression of a Novel $\alpha$-Amylase from Antarctic Psychrotolerant Fungus for Baking Industry and Its Magnetic Immobilization. BMC Biotechnology, 17, 22. https://doi.org/10.1186/s12896-017-0343-8

[19] Andriani, D., Sunwoo, C. and Park, D. (2012) Immobilization of Cellulase from Newly Isolated Strain Bacillus subtilis TD6 Using Calcium Alginate as a Support Material. Bioprocess and Biosystems Engineering, 35, 29-33. https://doi.org/10.1007/s00449-011-0630-Z

[20] Przybysz, A., Volmer, A.A., Westphal, A.H. and van Berkel, W.J. (2014) Bifunction-

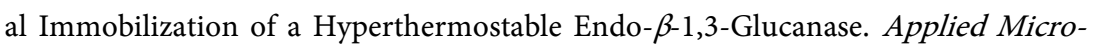
biology and Biotechnology, 98, 1155-1163. https://doi.org/10.1007/s00253-013-4953-3

[21] Inoue, A., Takadono, K., Nishiyama, R., Tajima, K., Kobayashi, T. and Ojima, T. (2014) Characterization of an Alginate Lyase, FlAlyA, from Flavobacterium sp. Strain UMI-01 and Its Expression in Escherichia coli. Marine Drugs, 12, 4693-4712. https://doi.org/10.3390/md12084693

[22] Inoue, A., Nishiyama, R. and Ojima, T. (2016) The Alginate Lyases FlAlyA, FlAlyB, FlAlyC, and FlAlex from Flavobacterium sp. UMI-01 Have Distinct Roles in the Complete Degradation of Alginate. Algal Research, 19, 355-362.

[23] Inoue, A., Nishiyama, R., Mochizuki, S. and Ojima, T. (2015) Identification of a 
4-Deoxy-L-Erythro-5-Hexoseulose Uronic Acid Reductase, FlRed, in an Alginolytic Bacterium Flavobacterium sp. Strain UMI-01. Marine Drugs, 13, 493-508. https://doi.org/10.3390/md13010493

[24] Laemmli, U.K. (1970) Cleavage of Structural Proteins during the Assembly of the Head of Bacteriophage T4. Nature, 227, 680-685. https://doi.org/10.1038/227680a0

[25] Lowry, O.H., Rosebrough, N.J., Farr, A.L. and Randall, R.J. (1951) Protein Measurement with the Folin Phenol Reagent. Journal of Biological Chemistry, 193, 265 275.

[26] Prado, F.E., González, J.A., Boero, C. and Sampietro, A.R. (1998) A Simple and Sensitive Method for Determining Reducing Sugars in Plant Tissues. Application to Quantify the Sugar Content in Quinoa (Chenopodium quinoa Willd.) Seedlings. Phytochemical Analysis, 9, 58-62. https://doi.org/10.1002/(SICI)1099-1565(199803/04)9:2<58::AID-PCA387>3.0.CO;2 $-\mathrm{Z}$

[27] Nelson, N. (1944) A Photometric Adaptation of the Somogyi Method for the Determination of Glucose. Journal of Biological Chemistry, 153, 375-380.

[28] Somogyi, M. (1952) Notes on Sugar Determination. Journal of Biological Chemistry, 195, 19-23.

[29] Illanes, A. and Altamirano, C. (2008) Enzyme Reactors. In: Illanes, A., Ed., Enzyme Biocatalysis, Springer, Berlin, 205-251.

https://doi.org/10.1007/978-1-4020-8361-7_5

[30] Obara, N., Ishida, M., Hamada-Sato, N. and Urano, N. (2012) Efficient Bioethanol Production from Paper Shredder Scrap by a Marine Derived Saccharomyces cerevisiae C-19. Studies in Science and Technology, 1, 127-132.

[31] Urano, N., Hirai, H., Ishida, M. and Kimura, S. (1998) Characterization of EthanolProducing Marine Yeasts Isolated from Coastal Water. Fisheries Science, 64, 633637.

[32] Altschul, S.F., Madden, T.L., Schaffer, A.A., Zhang, J., Zhang, Z., Miller, W. and Lipman, D.J. (1997) Gapped BLAST and PSI-BLAST: A New Generation of Protein Database Search Programs. Nucleic Acids Research, 25, 3389-3402. https://doi.org/10.1093/nar/25.17.3389

[33] Rasmussen, M.A., Madsen, S.M., Stougaard, P. and Johnsen, M.G. (2008) Flavobacterium sp. Strain 4221 and Pedobacter sp. Strain $4236 \beta$-1,3-Glucanases That Are Active at Low Temperatures. Applied and Environmental Microbiology, 74, 70707072. https://doi.org/10.1128/AEM.00681-08

[34] Abt, B., Lu, M., Misra, M., Han, C., Nolan, M., Lucas, S., Hammon, N., Deshpande, S., Cheng, J.-F., Tapia, R., Goodwin, L., Pitluck, S., Liolios, K., Pagani, I., Ivanova, N., Mavromatis, K., Ovchinikova, G., Pati, A., Chen, A., Palaniappan, K., Land, M., Hauser, L., Chang, Y.-J., Jeffries, C.D., Detter, J.C., Brambilla, E., Rohde, M., Tindall, B.J., Göker, M., Woyke, T., Bristow, J., Eisen, J.A., Markowitz, V., Hugenholtz, P., Kyrpides, N.C., Klenk, H.-P. and Lapidus, A. (2011) Complete Genome Sequence of Cellulophaga algicola Type Strain ( $\left.\mathrm{IC} 66^{\mathrm{T}}\right)$. Standards in Genomic Sciences, 4, 72-80. https://doi.org/10.4056/sigs.1543845

[35] Palumbo, J.D., Sullivan, R.F. and Kobayashi, D.Y. (2003) Molecular Characterization and Expression in Escherichia coli of Three $\beta$-1,3-Glucanase Genes from Lysobacter enzymogenes Strain N4-7. Journal of Bacteriology, 185, 4362-4370. https://doi.org/10.1128/JB.185.15.4362-4370.2003

[36] Thompson, J.D., Higgins, D.G. and Gibson, T.J. (1994) CLUSTAL W: Improving the Sensitivity of Progressive Multiple Sequence Alignment through Sequence Weighting, Position-Specific Gap Penalties and Weight Matrix Choice. Nucleic Ac- 
ids Research, 22, 4673-4680. https://doi.org/10.1093/nar/22.22.4673

[37] Planas, A. (2000) Bacterial 1,3-1,4- $\beta$-Glucanases: Structure, Function and Protein Engineering. Biochimica et Biophysica Acta (BBA)-Protein Structure and Molecular Enzymology, 1543, 361-382.

[38] Petersen, T.N., Brunak, S., Heijne, von Heijne, G. and Nielsen, H. (2011) SignalP 4.0: Discriminating Signal Peptides from Transmembrane Regions. Nature $\mathrm{Me}$ thods, 8, 785-786. https://doi.org/10.1038/nmeth.1701

[39] Care, A., Petroll, K., Gibson, E.S.Y., Bergquist, P.L. and Sunma, A. (2017) SolidBinding Peptides for Immobilisation of Thermostable Enzymes to Hydrolyse Biomass Polysaccharides. Biotechnology for Biofuels, 10, 29. https://doi.org/10.1186/s13068-017-0715-2

[40] Boraston, A.B., Bolam, D.N., Gilbert, H.J. and Davies, G.J. (2004) CarbohydrateBinding Modules: Fine-Tuning Polysaccharide Recognition. Biochemical Journal, 382, 769-781. https://doi.org/10.1042/BJ20040892

[41] Shoseyov, O., Shani, Z. and Levy, I. (2006) Carbohydrate Binding Modules: Biochemical Properties and Novel Applications. Microbiology and Molecular Biology Reviews, 70, 283-295. https://doi.org/10.1128/MMBR.00028-05

Submit or recommend next manuscript to SCIRP and we will provide best service for you:

Accepting pre-submission inquiries through Email, Facebook, LinkedIn, Twitter, etc. A wide selection of journals (inclusive of 9 subjects, more than 200 journals) Providing 24-hour high-quality service User-friendly online submission system Fair and swift peer-review system Efficient typesetting and proofreading procedure Display of the result of downloads and visits, as well as the number of cited articles Maximum dissemination of your research work

Submit your manuscript at: http://papersubmission.scirp.org/ Or contact aim@scirp.org 